\title{
On the natural history of the willow sawfly Nematus oligospilus (Hymenoptera,Tenthredinidae) inhabiting Salix humboldtiana, in Colombia
}

\author{
Leonardo A. Malagón-Aldana', Francisco Serna', David R. Smith \\ I Museo Entomológico UNAB, Grupo Sistemática de Insectos Agronomía SIA, Facultad de Ciencias Agrarias, Uni- \\ versidad Nacional de Colombia, Cra 30 \#45-03, Bogotá, D.C., Colombia 2 Systematic Entomology Laboratory, \\ Agricultural Research Service, U. S. Department of Agriculture, clo National Museum of Natural History, Smithsonian \\ Institution, P.O. Box 37012, MRC 168, Washington, D.C. 20013-7012, USA
}

Corresponding author: Leonardo A. Malagón-Aldana (landresmalagon@gmail.com.co)

Academic editor: M. Prous | Received 20 December 2016 | Accepted 13 February 2017 | Published 28 April 2017

http://zoobank.org/6D8168AF-9803-4F22-AAA1-649BD46A33DB

Citation: Malagón-Aldana LA, Francisco S, Smith DR (2017) On the natural history of the willow sawfly Nematus oligospilus (Hymenoptera, Tenthredinidae) inhabiting Salix humboldtiana, in Colombia. Journal of Hymenoptera Research 55: 189-199. https://doi.org/10.3897/jhr.55.11566

\begin{abstract}
The willow sawfly, Nematus oligospilus Förster, has recently been recorded from Colombia. Natural populations were searched for in Bogotá City, where one of the host plants, Salix humboldtiana, grows as an ornamental tree. Larvae and cocoons were found, which thrive on the leaves of this plant. Parthenogenetic reproduction of this sawfly was confirmed. Fecundity of every female was estimated through counting the number of eggs laid on the leaves of the host. In addition, some variations in the color pattern of the adult are described and several of its morphological traits measured. For the larval stage, the body length of each instar was measured and their stadium (intermoult period or instar duration) calculated. Six larval instars were observed regularly; only one case of seven instars occurred.
\end{abstract}

\section{Keywords}

Symphyta, development, introduced species, Neotropics, Bogotá

Copyright Leonardo A. Malagón-Aldana et al. This is an open access article distributed under the terms of the Creative Commons Attribution License (CC BY 4.0), which permits unrestricted use, distribution, and reproduction in any medium, provided the original author and source are credited. 


\section{Introduction}

The presence of the willow sawfly, Nematus oligospilus Förster, was recently recorded for Colombia (Malagón-Aldana et al., in press); two female specimens were found deposited at different entomological collections (Entomological Museum UNAB and the biological collection from Alexander Von Humboldt Institute IAvH), both distributed in central region of Colombia, departments of Cundinamarca and Boyacá. In early 1980s, this species was recorded for the first time for southern South America, in Argentina and Chile (Smith 1983, González et al. 1986, Dapoto and Giganti 1994, Koch and Smith 2000), where this introduced species is a pest occurring at very high larval densities, causing severe defoliation, tree mortality, and economic losses on plantations of different species of Salix (Dapoto and Giganti 1994). Populations identified as $N$. oligospilus in different regions of the world could involve different members of a species group (Koch and Smith 2000, Smith 2003, Caron et al. 2013a).

The natural history of $N$. oligospilus has been addressed in several studies from different biogeographical regions (De Santis and De Sureda 1984, Dapoto and Giganti 1994, Urban and Eardley 1995, Ede et al. 2007, Alderete et al. 2010). Some common features regarding these studies include absence of males and reproduction by parthenogenesis (apomictic thelytoky) in the invasive populations (De Santis and De Sureda 1984, González et al. 1986, Ede et al. 2007, Caron et al 2013b). Regarding immature forms, larvae hibernate as prepupae when their deciduous hosts lose their leaves; the larvae move from the host into the soil, where they build cocoons and dwell until spring when they pupate and adults eventually emerge (Ede et al. 2007). A small proportion of the population may pupate directly either on leaves or trunks within the summer and winter season (Dapoto and Giganti 1994, Alderete et al. 2010). Concerning their development, stadia (timing) of various stages have been estimated several times (Ede et al. 2007), the number of larval instars varies between four to seven (González et al. 1986, Ovruski 1991, Charles and Allan 2000). However, little information of the intermoult growth and stadia of larval instars has been reported. As to their natural enemies, several parasitoids of the families Ichneumonidae, Eurytomidae, Pteromalidae, Eulophidae, Eupelmidae, and Chalcididae, as well as predators of the families Pentatomidae and Vespidae have been recorded (De Santis and De Sureda 1984, González et al. 1986, Dapoto and Giganti 1994).

In Colombia, Salix is represented primarily by the species $S$. humboldtiana (Alford 2015), which is naturally distributed from Mexico to Argentina (STRI 2015). Likewise, though much less common, some introduced species, including S. babylonica, S. viminalis, and $S$. purpurea have also been recorded. Contrary to other countries in the region, in Colombia there are no extensive plantations of Salix spp.; the main purpose of urban plantings of the introduced species are ornamental, landscaping, soil conservation, and protection of water bodies. In cities such as Bogotá, the planted trees of $S$. humboldtiana are easily found, albeit scattered.

Based on a previous record of some specimens of $N$. oligospilus from localities in central Colombia, and the abundance of Salix humboldtiana thriving in Bogotá City, 
the main goals of this study were to discover populations of $N$. oligospilus in the city, corroborate parthenogenetic reproducing populations, the presence/absence of males, and highlight some traits of the populations, including phenotypic variation of adults, larval development, oviposition behavior, and occurrence of parasitoids.

\section{Materials and methods}

\section{Field work}

To locate the larvae, cocoons, or any other indication of the occurrence of $N$. oligospilus, we inspected approximately 25 trees of $S$. humboldtiana scattered around Bogotá, including the campus of the Universidad Nacional de Colombia. Following recommendations from the literature (Charles and Allan 2000, Loetti et al. 2012), we collected branches with numerous leaves, on heights between 0 and $3 \mathrm{~m}$ on each tree, for 10 to 15 minutes per tree. Sampling was carried out during July and August, 2015, from $10 \mathrm{am}$ to $4 \mathrm{pm}$. The foliage accumulated was placed into several plastic boxes and transported to the laboratory.

\section{Laboratory procedures and data analysis}

Laboratory work was conducted at the Entomological Museum UNAB (Universidad Nacional Agronomía Bogotá). Several specimens were mounted, curated, and housed in the Central Taxonomic Collection (CTC) of UNAB, following the curatorial standards of Martínez-Alava and Serna (2015). To confirm the identity of the collected specimens, we needed adults, because this is the main stage of development for which taxonomic keys, diagnosis, and descriptions are available (Benson 1958, Förster 1854, Koch and Smith 2000, Smith 2003). To obtain adults, the larvae and in-cocoon pupae were put individually in Petri dishes. Larvae were maintained with leaves of $S$. humboldtiana, while cocoons were placed on a filter paper that was the same size as the Petri dish, and into which 10 drops of water was daily applied to guarantee moisture. The breeding was kept at room temperature (with oscillations between $5-18{ }^{\circ} \mathrm{C}$, between night and day).

All stages of development were observed under a Nikon SMZ-1 stereo microscope. Measurements were taken with a micrometric scale, and photographs were taken with a Canon EOS RevelXS camera, adapted to the stereo microscope. Adult specimens were preserved in 96\%-ethanol. The ovipositors were cleared in $10 \% \mathrm{KOH}$ for 12 hours, then cleaned in diluted acetic acid ( 3 drops into $30 \mathrm{ml}$ of distilled water) for one minute, and subsequently rinsed in $75 \%$ and $96 \%$ ethanol for 5 minutes each; finally, they were slide-mounted, using Canada balsam partially diluted with Xylene. To observe details of the ovipositor, an Olympus CX31 microscope was employed. Morphological terminology was based on Snodgrass (1935), Gibson $(1985,1993)$ and Viitasaari (2002). 


\section{Results}

\section{Field collections}

Larvae, pupae, and cocoons of Nematus oligospilus were found on the collected foliage of $S$. humboldtiana. Populations of N. oligospilus had low densities, 1-10 individuals per tree, including the larvae and pupae. We did not observe any adults in the field. The green color of eggs, larvae and cocoons of the sawfly made them cryptic on the willow leaves. Neither the individuals nor their damage were immediately noticeable in the trees examined. No symptoms from moderate to severe defoliation occurred.

Fifteen adult females were obtained from rearing. These specimens are housed in the CTC, UNAB (Figs 1-6), with the following data: COLOMBIA, Cundinamarca, Bogotá, Campus Universidad Nacional de Colombia, N 4³8'34", W 7404'58", 2600 m, Ago.-2015, L. Malagón (11 +); COLOMBIA, Cundinamarca, Bogotá, Barrio Guacamayas, N 4³3'09", W7405'49", 2730 m, 22-Ago-2015, L. Malagón (2 + ); COLOMBIA, Cundinamarca, Bogotá, Barrio Santa Ana Occidental, N4²1'36", W7402'23", 2580 m, 19-Ago-2015, L. Malagón (2 ㅇ). All under catalogue number 733.

\section{Phenotypic variation of females}

Supplemental to the descriptions by Koch and Smith (2000) and Smith (2003), information about some variation may be useful in recognizing females of $N$. oligospilus.

Measurements $(\mathrm{n}=15)$ : Total length $5.3-7.8 \mathrm{~mm}$; ranges of metric ratios include antenna length / head width 3-3.2; lower interocular distance/ eye length 1.8-1.9; upper interocular distance/ eye length 1.7-1.8; width / length of postocellar area 2-2.5; malar space length / median ocellus diameter 1.4-1.6; cercus length / valvulae 3 length, in dorsal view, $0.7-0.8$.

Color. Head (Figs 4, 5): vertex, genae, and frons above antennae dark yellow; facial area below antennae, including clypeus, labrum, and malar areas pale yellow; limit between vertex and occiput either with or without a mesal triangular black spot; areas surrounding ocelli containing linear black spots; frons lacking a black spot; in living individuals, all areas of head lack green color. Antenna black, being clearer distally to the third flagellomere. Mandible yellow, with a brown apical tooth. Thorax (Figs 1, 2): pronotum light yellow; propleuron yellow, with its anterodorsal margin from black to entirely yellow; basalare, tegula, and postspiracular sclerite yellow; mesoscutum reddish yellow, with lateral lobes either having or lacking black spots; antecostal suture and medial sulcus of mesoscutum black; axilla from entirely black to white, or with a black spot on the disc of its posterior margin; mesoscutellum yellow, with its posterior margin black to yellow entirely; mesopostnotum white with a black discal spot; middle of upper half of mesepisternum pale yellow, and middle of lateroventral lower area reddish yellow; epicnemium yellow; metascutum white, with cenchri yellow; metascutellum dark 


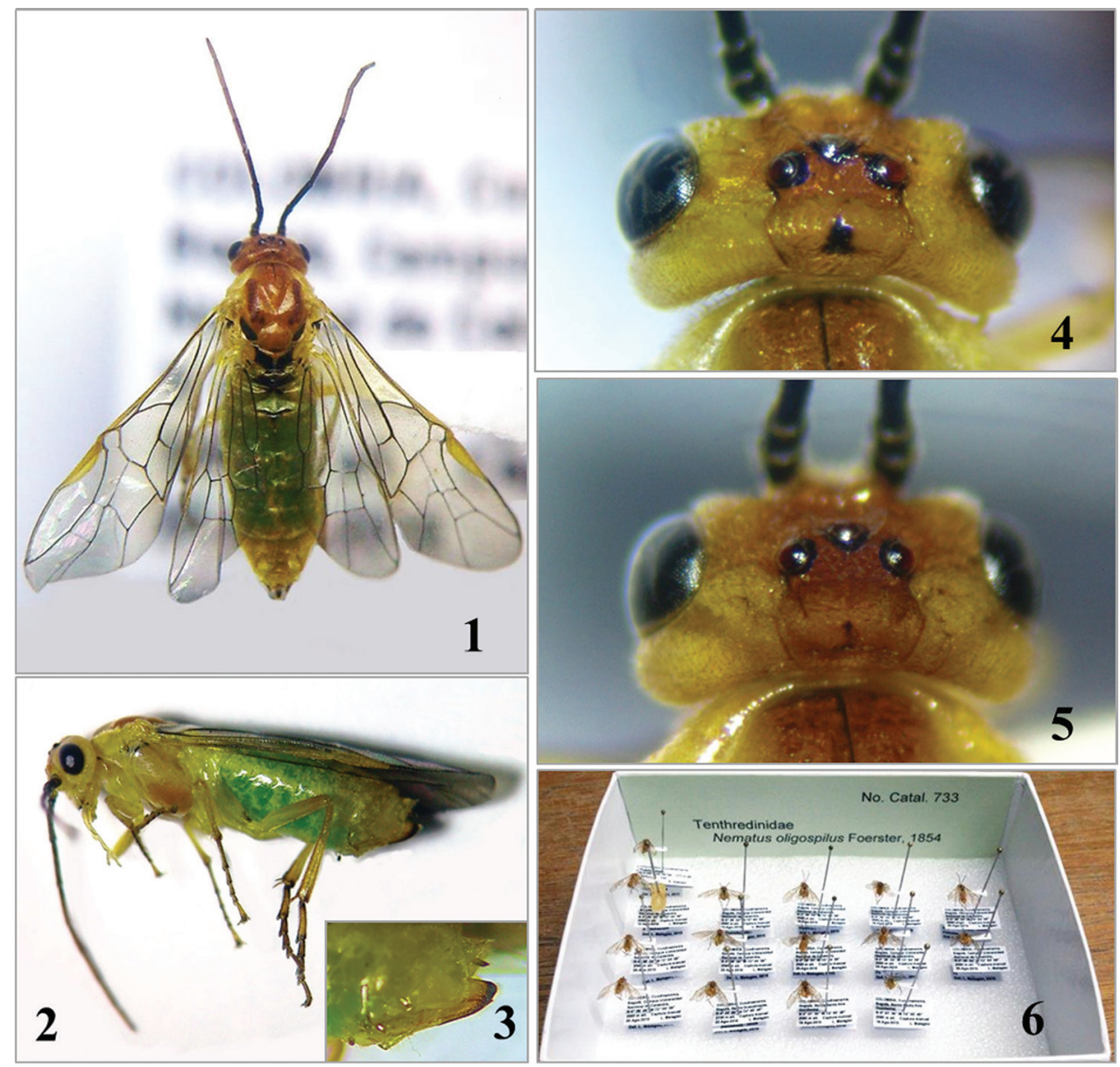

Figures I-6. Nematus oligospilus, + , reared from immatures collected on Salix humboldtiana (Salicaceae) in Bogotá, Colombia. I Dorsal view 2 Lateral view 3 Ovipositor sheath, lateral view 4 Vertex with a conspicuous black spot $\mathbf{5}$ Vertex with a reduced black spot $\mathbf{6}$ Housed specimens at the Entomological Museum UNAB (Catal. Number 733).

yellow with posterior margin black to entirely black; metapleuron and metasternum yellow; metapostnotum black mesally and white laterally. Abdomen: Green in living individuals, segments VII-X yellow (green color sometimes preserved (Figs 1, 2), but the entire abdomen usually turns yellow in mounted specimens); urotergites (segmental abdominal terga) I, II and III with or without black wide medial spot, which when present may be very narrow and anteroposteriorly extended on dorsum, as a longitudinal medial line. Legs (Fig. 2): yellow, darker on each segment apically. Genitalia: valvulae 1 (= lancet) and 2 (= lance) hyaline yellow, with annuli dark yellow; valvula 3 (= sheath) (Fig. 3) dark yellow, with posteroventral margin black; cerci dark brown. Wings hyaline (Fig. 1); Costal vein and pterostigma yellow; remaining veins dark brown. 
Table I. Fecundity and longevity of $N$. oligospilus in laboratory. Females, $\mathrm{n}=15$; pupae, $\mathrm{n}=15$; larvae, $\mathrm{n}=11$ (from several instars); eggs, $\mathrm{n}=490$.

\begin{tabular}{|c|c|c|c|c|c|c|c|c|c|c|c|}
\hline & \multicolumn{2}{|c|}{ Fecundity } & & \multicolumn{8}{|c|}{ longevity (days) } \\
\hline & \multirow{2}{*}{$\begin{array}{l}\text { number of } \\
\text { eggs/female }\end{array}$} & \multirow{2}{*}{$\begin{array}{c}\text { number of } \\
\text { eggs/leaf }\end{array}$} & & \multicolumn{6}{|c|}{ Larval instar } & \multirow{2}{*}{$\begin{array}{c}\text { Pupae } \\
\text { (in cocoon) }\end{array}$} & \multirow{2}{*}{ Adult } \\
\hline & & & & 1 & 2 & 3 & 4 & 5 & 6 & & \\
\hline Maximum & 53 & 17 & Maximum & 8 & 2 & 3 & 3 & 4 & 4 & 11 & 9 \\
\hline Average & 30 & 3.7 & Average & 6.5 & 2 & 3 & 3 & 4 & 3 & 9.78 & 7.1 \\
\hline Minimum & 9 & 1 & Minimum & 5 & 2 & 3 & 3 & 4 & 2 & 9 & 4 \\
\hline
\end{tabular}

\section{Notes on the development of $N$. oligospilus on S. humboldtiana in Bogotá}

From the immature forms reared in the lab, we obtained only females. Immediately after emergence, a female lays an average of 31 eggs $(n=15)$ on the leaves of the host plant (Table 1). Postembryonic development lasts from 32 to 44 days (Table 1). The larval stage has the longest time span, between 19 and 24 days. Most eggs obtained in the lab did not hatch, a few viable eggs lasted between six and eight days before hatching.

Six larval instars $(\mathrm{n}=10)$ were recognized; each instar varied in size; most instars did not overlap in body length, except $5^{\text {th }}$ and $6^{\text {th }}$ where overlap was close to $0.15 \mathrm{~mm}$. Regarding intermoult size increment (Gullan and Cranston 2014), $3^{\text {rd }}$ instar had the lowest $(0.1 \mathrm{~mm})$ and the $5^{\text {th }}$ instar the highest $(0.55 \mathrm{~mm})$. Concerning stadia (Gullan and Cranston 2014), intermoult duration was highest in the 1st instar, varying between five and eight days, while $2^{\text {nd }}$ instar had a two-day shortest stadium (Table 1). One larva went through seven instars.

Darkening of the head capsule of the larvae in early instars marks the initiation of the moulting process (Fig. 8). Right after completing each ecdysis, the new larvae are light green (except for eyes and mandibles) (Fig. 9). Prepupae build the cocoon and pupate directly on foliage of Salix humboldtiana (Figs 12,13). In the lab, larval ecdysis tends to occur during night hours, whereas adults emerge around noon. No parasitoids were obtained from the reared larvae or pupae.

\section{Oviposition behavior}

For oviposition, the first and second valvulae work together as a sharp structure tapering distally. With the teeth of ventral margin of the $1^{\text {st }}$ valvula of the ovipositor, the sawfly produces an incision in the cuticle of the leaf, generating a small swelling (Fig. 14) in the epidermis or between the epidermis and the chlorenchyma (Braccini et al. 2013). During oviposition, the valvulae are inserted in the leaf initially in a position perpendicular to the body axis; as the valvulae penetrate deeper, they rotate anteriorly, being parallel to the body axis at the end of oviposition. This forms a kidney-shaped pocket, which is immediately filled with an egg, turning back the ovipositor in the opposite direction. 


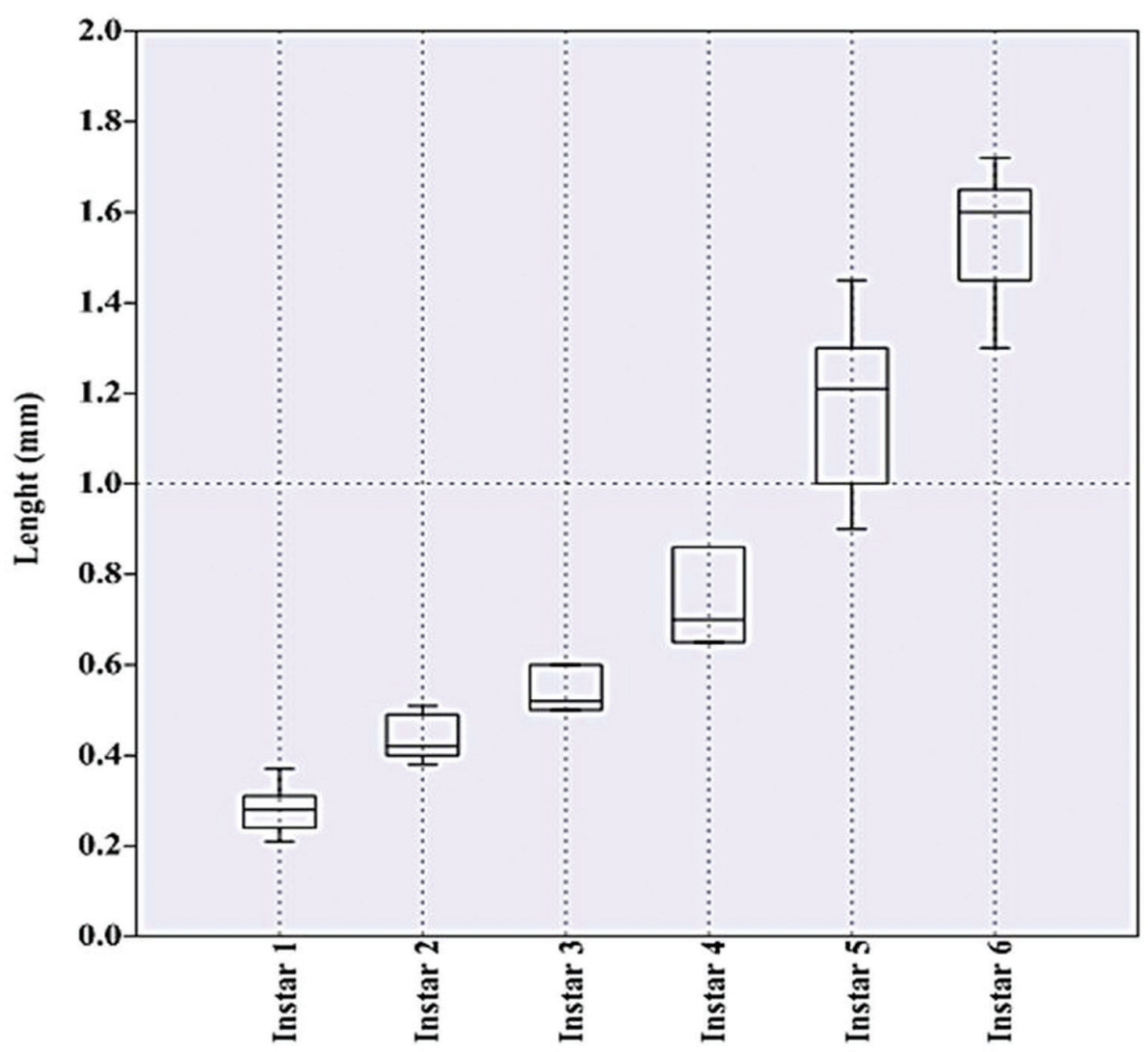

Figure 7. Box-whisker plot of total length variation with reference to each larval instar $(n=10)$.

\section{Discussion}

The presence of $N$. oligospilus in Colombia was confirmed by finding specimens feeding on the foliage of Salix humboldtiana, in the City of Bogotá. According to records from other parts of South America, $N$. oligospilus is distributed between 0 and $1700 \mathrm{~m}$ above sea level (Koch and Smith 2000); in Colombia it reaches higher elevations (2600m) in Bogotá.

Regarding phenotypic characters of this species, contrary to what was written by Koch and Smith (2000) for the lectotype, we did not find black spots on the frons or on the interocellar area; additionally, we observed intraspecific variation in the coloration of the individuals reared in the lab. Whereas the specimens housed in different collections have black color pattern characteristic of the species, the adults we reared lack or have the triangular spot on the vertex reduced, whereas the spots on the mesoscutum and abdominal terga are retained. Similar variations regarding the reduction of spots and black color patterns are found in specimens from several countries around the world (Koch and Smith 2000). Characteristics of the ovipositor agree with other descriptions (Malagón-Aldana et al., in press); similarly, the coloration of the larva coincides with what is described in the literature. 

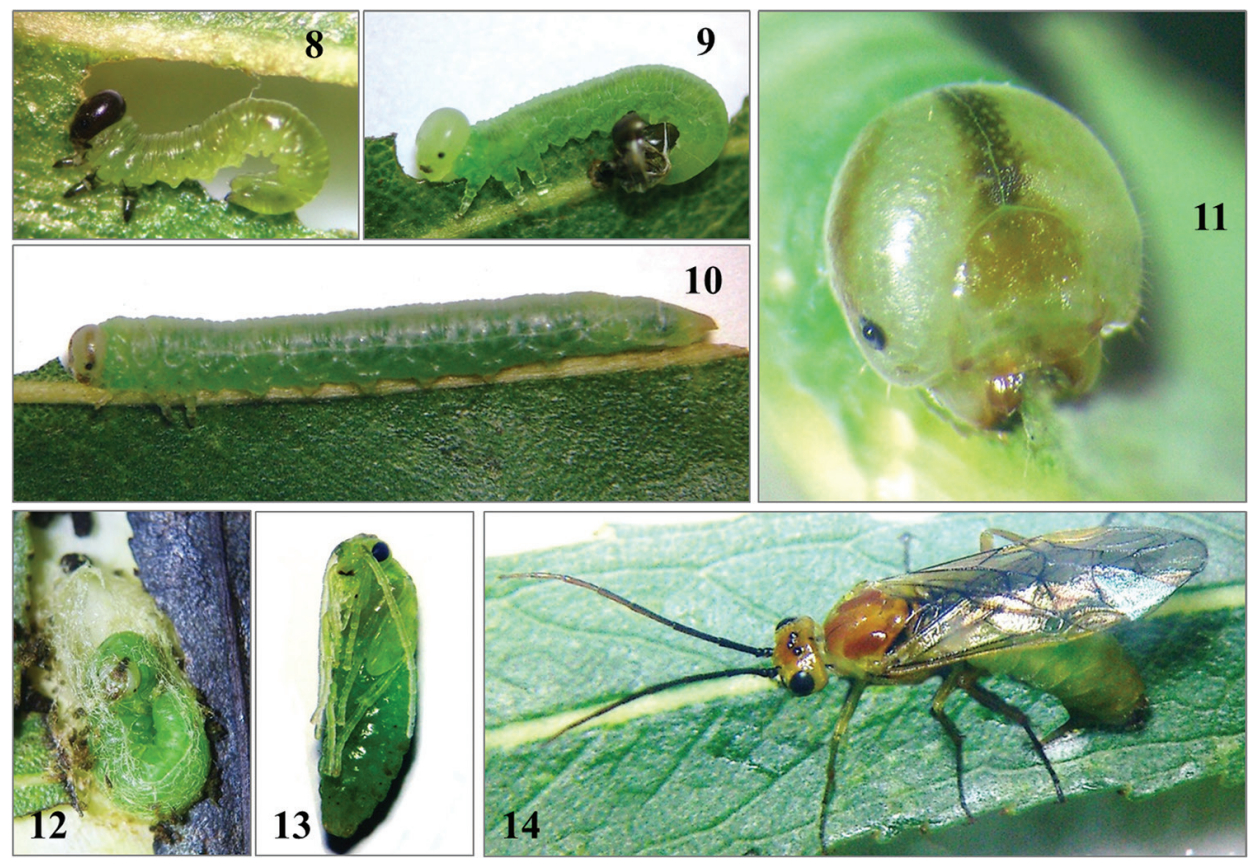

Figures 8-14. Nematus oligospilus. 8 Larval instar 1 immediately before ecdysis 9 Larval instar 3 immediately after ecdysis $\mathbf{0}$ Larval instar 6 feeding on a leaf of Salix humboldtiana I I Frontal view of head of $6^{\text {th }}$ larval instar I 2 A sixth larval instar spinning its own cocoon 13 Pupa 14 A female ovipositing.

Parthenogenetic reproduction is confirmed in $N$. oligospilus. For the first time, we observed and compared the different intermoult larval instar stadia and growth; likewise, the number of larval instars coincides with the data in Ovruski (1991) and Charles and Allan (2000); other development stages agree with data recorded in different studies (Ede et al. 2007). Contrary to what was previously reported for other parts of the Southern Hemisphere (Ede et al. 2007), the larvae of N. oligospilus in Colombia make cocoons directly on leaves of $S$. humboldtiana and not in the soil. This difference is probably due to climate seasonality in other regions, usually subtropical (Argentina, South Africa, Australia), where the photoperiod and temperature change abruptly from one season to the next (especially winter and spring), and favoring strategies as winter diapause (Ede et al. 2007), and pupation underground.

Compared to other countries in the Southern Hemisphere, population densities of $N$. oligospilus are low in Bogotá. It is noteworthy that in different studies $S$. humboldtiana and its varieties exhibit lower levels of both oviposition and phytophagy by the willow sawfly (Cerillo et al. 2011, Braccini et al. 2013), compared to exotic species such as S. nigra, S. babylonica, S. alba, and S. matsudana. Moreover, in the other countries where the introduction of $N$. oligospilus has been recorded, there are extensive commercial plantations, or additional natural communities of Salix spp., which favor establishing sawfly populations. 
In Colombia, the larvae seldom devour the leaves entirely. This behavior is similar to that described by Carr et al. (1998) in native populations of $N$. oligospilus in Arizona, on Salix lasiolepis (Arroyo Willow), the sawfly displays moderate movements between leaves, and populations remain low and stable.

Concerning the expansion of the distribution of this sawfly from Argentina, and the wide distribution of $S$. humboldtiana in South America, it is likely that N. oligospilus is present in neighboring countries. In Colombia, it is necessary to determine whether this sawfly is also present on other species of planted Salix.

\section{Acknowledgments}

Marko Prous, Veli Vikberg, Jean-Luc Boevé and Lars Vilhelmsen provided very important suggestions to the manuscript. We thank UNAB museum, for providing the equipment and space for the development of this study. Also, we thank Javier Martínez, who produced some photographs, Diana Suárez and Helber Arévalo who supported collecting process in the field, and Valentina Vergara who cataloged collected specimens.

\section{References}

Alford MH (2015) Salix humboldtiana Willd. In: Bernal R, Gradstein SR, Celis M (Eds) Catálogo de plantas y líquenes de Colombia. Instituto de Ciencias Naturales, Universidad Nacional de Colombia, Bogotá. http://catalogoplantascolombia.unal.edu.co

Alderete M, Liljesthrom G, Hidalgo P (2010) Bio-ecología y perspectivas para el manejo de la avispa sierra del sauce, Nematus oligospilus. In: Villacide J, Corley J (Eds) Serie Técnica: Manejo Integrado de Plagas Forestales. Cuadernillo 10, 10 pp.

Benson RB (1958) Hymenoptera, Symphyta. Handbooks for the Identification of British Insects 6(2c): 139-252.

Braccini CL, Vega AS, Chludil HD, Leicach SR, Fernandez PC (2013) Host selection, oviposition behaviour and leaf traits in a specialist willow sawfly on species of Salix (Salicaceae). Ecological Entomology 38: 617-626. doi: 10.1111/een.12053

Carr TG, Roininen H, Price PW (1998) Oviposition preference and larval performance of Nematus oligospilus (Hymenoptera: Tenthredinidae) in relation to host plant vigor. Environmental Entomology 27(3): 615-625.

Caron V, Ede F, Sunnucks P, O'Dowd DJ (2013a) Distribution and rapid range expansion of the introduced willow sawfly Nematus oligospilus Förster in Australasia. Austral Entomology 53: 175-182. doi: 10.1111/aen.12067

Caron V, Norgate M, Ede FJ, Nyman T, Sunnucks P (2013b) Novel microsatellite DNA markers indicate strict parthenogenesis and few genotypes in the invasive willow sawfly Nematus oligospilus. Bulletin of Entomological Research 103: 74-88.

Cerrillo T, Braccini C, Martínez R, Chludil H, Leicach S, Fernández P (2011) Susceptibilidad de distintos genotipos experimentales de Salix spp. a la avispa sierra Nematus oligospilus - 
Evaluación de daños a campo y estudios de preferencia en laboratorio. Trabajo técnico, Tercer Congreso Internacional de Salicáceas en Argentina.

Charles JG, Allan DJ (2000) Development of the willow sawfly, Nematus oligospilus, at different temperatures, and an estimation of voltinism throughout New Zealand. New Zealand Journal of Zoology 27(3): 197-200.

Dapoto G, Giganti H (1994) Bioecologia de Nematus desantisi Smith (Hymenoptera: Tenthredinidae: Nematinae) en las provincias de Rio Negro y Neuquen (Argentina). Bosque 15: 27-32.

De Santis L, De Sureda G (1984) La falsa oruga de los sauces y álamos (Nematus desantisi). Academia Nacional de Agronomía y Veterinaria (Buenos Aires) 38(7): 1-22.

Ede FJ, Caron V, Clements D (2007) Willow Sawfly Activity in Victoria: The 2006/07 Season. Victorian Department of Primary Industries, Frankston, Australia.

Förster A (1854) Neue Blattwespen. Verhandlungen des Naturhistorischen Vereins der Preussichen Rheinlande 11: 265-350.

Gibson GAP (1985) Some pro- and mesothoracic structures important for phylogenetic analysis of Hymenoptera, with a review of the terms used for the structures. Canadian Entomologist 117: 1395-1443.

Gibson GAP (1993) Groundplan structure and homology of the pleuron in Hymenoptera based on a comparison of the skeletomusculature of Xyelidae (Hymenoptera) and Raphidiidae (Neuroptera). In: Ball GEB, Danks H (Eds) Systematics and Entomology: Diversity, Distribution, Adaptation and Application. Memoirs of the Entomological Society of Canada 165: 165-187.

González RH, Barría G, Guerrero MA (1986) Nematus desantisi Smith, a new species of forest importance in Chile (Hymenoptera: Tenthredinidae). Revista Chilena de Entomología 14: $13-15$.

Gullan PJ, Cranston PS (2014) The Insects: An Outline of Entomology ( $\left.5^{\text {th }} \mathrm{edn}\right)$. WileyBlackwell, $624 \mathrm{pp}$.

Koch F, Smith DR (2000) Nematus oligospilus Förster (Hymenoptera: Tenthredinidae), an introduced willow sawfly in the Southern Hemisphere. Proceedings of the Entomological Society of Washington 102: 292-300.

Loetti V, Rubio A, Bellocq MI (2012) Feeding preferences of the willow sawfly Nematus oligospilus (Hymenoptera: Tenthredinidae) for commercial Salix clones. Revista de la Sociedad Entomológica Argentina 71(1/2): 145-150.

Malagón-Aldana L, Serna F, Smith DR (in press) The introduced willow sawfly Nematus oligospilus (Hymenoptera: Tenthredinidae: Nematinae): first record for Colombia and in north of northern South America, Colombia, with some notes of on its ovipositor anatomy. Entomological news.

Martínez-Alava JO, Serna F (2015) Managing insect collections. Micropezidae (Diptera: Nerioidea) of the Entomological Museum UNAB. Agronomía Colombiana 33(3): 339-347.

Ovruski S (1991) Estudios biológicos y ecológicos de la falsa oruga de los sauces y álamos (Nematus desantisi) y consideraciones sobre su distribución. Trabajo de seminario para optar al título de Licenciatura en Ciencias Biológicas, orientación Zoología, Universidad Nacional de Tucumán, Facultad de Ciencias Naturales e Inst. M. Lillo. Mecanografiado, 94 pp. 
Ovruski S, Smith DR (1993) Descriptions of immature stages of Nematus desantisi (Hymenoptera: Tenthredinidae), a pest of Salicaceae in Argentina and Chile. Entomological News 104(4): 153-160.

Smith DR (1983) The first record of Nematus Panzer from South America: A new species from Argentina (Hymenoptera: Tenthredinidae). Proceedings of the Entomological Society of Washington 85: 260-262.

Smith DR (2003) A synopsis of the sawflies (Hymenoptera: Symphyta) of America south of the United States: Tenthredinidae (Nematinae, Heterarthrinae, Tenthredininae). Transactions of the American Entomological Society 129: 1-45.

Snodgrass RE (1935) Principles of Insect Morphology. Comstock Publishing Associates, London, $667 \mathrm{pp}$.

STRI Smithsonian tropical research Institute (2015) http://biogeodb.stri.si.edu/herbarium/ species/25561/?search_key=salix+humboldtiana

Urban AJ, Eardley CD (1995) A recently introduced sawfly, Nematus oligospilus Forster (Hymenoptera: Tenthredinidae), that defoliates willows in southern Africa. African Entomology 3: 23-27.

Viitasaari M (2002) The suborder Symphyta of the Hymenoptera, external morphology. In: Viitasaari M (Ed.) Sawflies (Hymenoptera, Symphyta) 1. Tremex Press, Helsinki, 108-174. 